\title{
12. CRUSTAL SUBSIDENCE AND CALCITE DEPOSITION IN THE SOUTH PACIFIC OCEAN1
}

\author{
David K. Rea, Department of Atmospheric and Oceanic Science, The University of Michigan \\ and \\ Margaret Leinen, Graduate School of Oceanography, The University of Rhode Island ${ }^{2}$
}

\begin{abstract}
Patterns of crustal subsidence in the southeast Pacific Ocean reflect the complex tectonic history of that region. A plot of the depth-time history of calcite accumulation recorded at DSDP sites beneath the oligotrophic subtropical gyre allows us to define the Neogene history of the calcite compensation depth (CCD) and the lysocline. The CCD shoaled from 4200 to $3700 \mathrm{~m}$ between 24 and $20 \mathrm{Ma}$ and then deepened to near the present depth of $4100 \mathrm{~m}$ by $5 \mathrm{Ma}$. The lysocline became distinctly separate from the CCD between 20 and $17 \mathrm{Ma}$. By $14 \mathrm{Ma}$, the lysocline rose to $600 \mathrm{~m}$ above the CCD, where it has remained until the present. We interpret these data to reflect an increase in the volume of Antarctic Bottom Water beginning at 18 or $19 \mathrm{Ma}$ and reaching a steady-state condition by $14 \mathrm{Ma}$, the time of rapid ice build-up in Antarctica.
\end{abstract}

\section{INTRODUCTION}

\section{Carbonate Dissolution}

Early workers in marine geology realized that throughout most of the deep ocean the calcium carbonate microfossil tests generated in surface waters dissolved before they could be incorporated into the sediments (Murray and Renard, 1891). Experiments in the Pacific Ocean done by Peterson $(1966)$ and Berger $(1967,1970)$ showed that calcite dissolution did not increase linearly with depth but rather that little dissolution occurred above about $3500 \mathrm{~m}$ and rapid dissolution occurred at depths greater than this. This depth zone of rapidly increasing dissolution rate is called the lysocline (Berger, 1968, 1970), and that depth where the dissolution rate of calcite matches the supply rate, and below which there is no net $\mathrm{CaCO}_{3}$ accumulation, is called the calcite compensation depth (CCD) (Bramlette, 1961; Heath and Culberson, 1970).

Heath (1969) studied calcium carbonate deposition in the equatorial Pacific and suggested changes in the CCD through Cenozoic time. Berger (1973) was the first to incorporate seafloor subsidence history into Pacific CCD studies; he used an empirical age-depth curve similar to that compiled by Sclater et al. (1971). Results of this study of equatorial Pacific sediments gave the first reasonable estimate of the equatorial Pacific CCD history. An important feature of this history is the significant deepening of the CCD from about 4000 to $4800 \mathrm{~m}$ at 35 to $40 \mathrm{Ma}$. Van Andel and his co-workers used empirical subsidence curves and all DSDP data then available to determine the CCD histories for the equatorial and nonequatorial Pacific (van Andel and Bukry, 1973; van Andel and Moore, 1974; van Andel et al., 1975). Results of these efforts refined the earlier results of Berger for the equatorial region and showed that away from

\footnotetext{
${ }^{1}$ Leinen, M., Rea, D. K., et al., Init. Repts. DSDP, 92: Washington (U.S. Govt. Printing Office).

2 Addresses: (Rea) Oceanography Program, Department of Atmospheric and Oceanic Science, The University of Michigan, Ann Arbor, MI 48109; (Leinen) Graduate School of Oceanography, The University of Rhode Island, Narragansett, RI 02882.
}

the equator the $\mathrm{CCD}$ has been about $600 \mathrm{~m}$ shallower, at 4000 to $4200 \mathrm{~m}$, since the early Oligocene. Studies of piston cores (Broecker and Broecker, 1974) and surface sediments (Berger et al., 1976) from the South Pacific have shown the present CCD to be at about $4100 \mathrm{~m}$ depth and the top of the lysocline to be near $3500 \mathrm{~m}$.

\section{Crustal Subsidence}

Sclater et al. (1971) developed empirical age-depth curves for the seafloor using magnetic anomaly ages and observed water depths. Berger (1973) used a similar subsidence curve with an assumed paleodepth of the ridge axis of $2700 \mathrm{~m}$ to hindcast ocean depths. Berger also recognized that basement was depressed by the sediment load by an amount approximately equal to half the sediment thickness.

Van Andel and Bukry (1973) compiled another empirical age-depth curve for the Pacific from basement depths and ages at DSDP sites. Their curve, which does not account for sediment loading, lies a few hundred meters below that of Sclater et al. (1971). In their studies of CCD history, van Andel and Moore (1974) and van Andel et al. (1975) utilized this same curve to backtrack depths at each drill site through time.

Parker and Oldenburg (1973) and Davis and Lister (1974) quantified the empirical age-depth relationship and demonstrated that ocean floor depth $(Z)$ can be expressed as a function of age $(t)$. Davis and Lister (1974) showed that the slope of a line $Z t^{1 / 2}$ is relatively constant for any given area. Rea (1976) used this relation to define crustal subsidence at $10^{\circ} \mathrm{S}$ on the East Pacific Rise. Crustal depths at this location fit the general form

$$
Z(\mathrm{~km})=Z a(\mathrm{~km})+k t^{1 / 2}
$$

where $Z a$ is the paleodepth of the ridge axis, $t$ is basement age in $\mathrm{Ma}$, and $k$ is a proportionality factor that defines the slope of the seafloor. This factor, $k$, is the subsidence parameter, and it generally falls in the range from 0.25 to 0.4 . 


\section{PROCEDURE AND DATA}

Data from the four drilling locations occupied by the Glomar Challenger during Leg 92 (Fig. 1) double the available information on the history of the CCD in the South Pacific and provide some insight into the development of a lysocline that is distinctly shallower than the CCD. The first step in determining this information is to determine the subsidence curve for each site by using the relationship $Z=Z a+k t^{1 / 2}$. Previous studies have implicitly assumed either that both $Z a$ and $k$ are constant (Berger, 1973) or that $k$ is constant and $Z a$ has changed (van Andel and Moore, 1974; van Andel et al., 1975). Inspection of age-depth plots of South Pacific drill sites (Fig. 2) shows sites of similar depth and different age (Sites 598 and 599) and sites of similar age but $600 \mathrm{~m}$ apart in depth (Sites 598 and 319). We conclude from the information given in Figure 2 that the subsidence parameter $k$ must be different for different sites. To make the calculations more manageable, and because

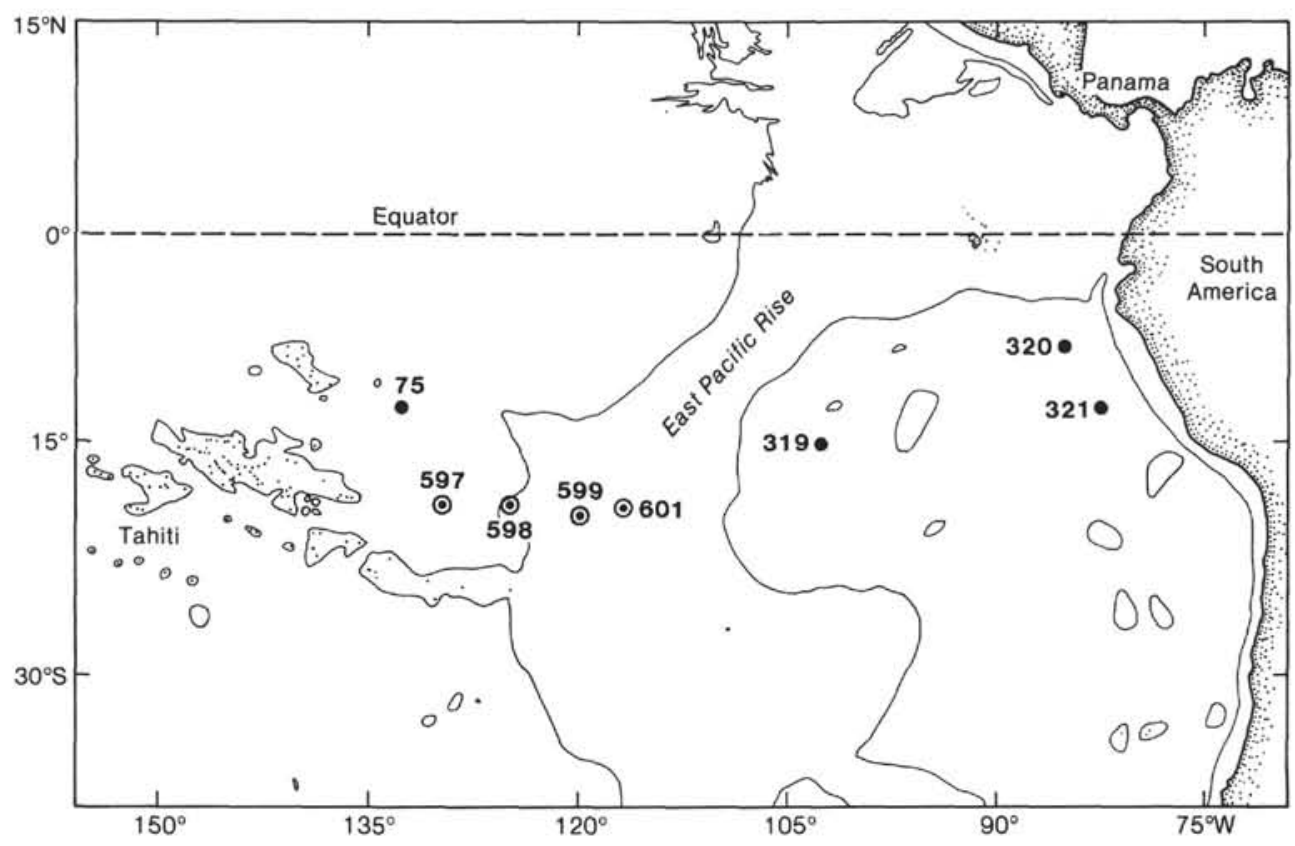

Figure 1. Index map of the South Pacific showing sites used to construct the subsidence and CCD history of the region. Circled dots $=$ Leg 92 sites.

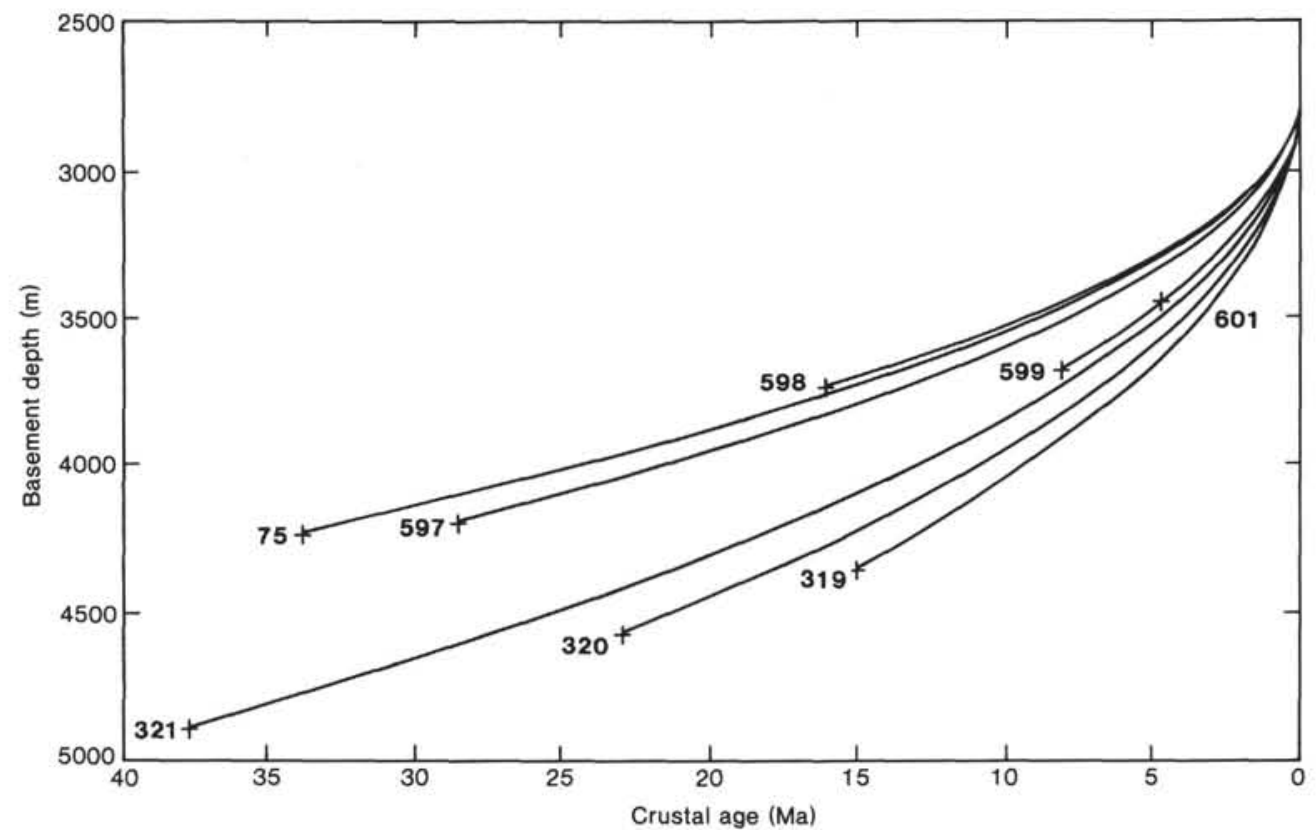

Figure 2. Subsidence curves for DSDP sites in the South Pacific. Curves calculated from the relationship $Z$ $=2.75(\mathrm{~km})+k t^{1 / 2}$ (see text for further details). 
it is a more reasonable assumption, we assume a constant paleodepth for the rise axis $\mathrm{Za}$. We chose $2.75 \mathrm{~km}$ for the past axial depth because this is a good approximation, usually within 50 to $100 \mathrm{~m}$, of present-day axial depths along the Pacific-Nazca portion of the modern East Pacific Rise north of the Easter microplate (Rea, 1981). Resulting subsidence curves are shown in Figure 2; the various parameters, including basement depth after sediment "unloading," are listed in Table 1. Tectonic histories of the southeast Pacific (Handschumacher, 1976; Mammerickx et al., 1980) imply little latitudinal shift of the sites since Oligocene time.

The history of $\mathrm{CaCO}_{3}$ deposition is taken from the site chapters in the Initial Reports for Leg 8 (Tracey, Sutton, et al., 1971), Leg 34 (Yeats, Hart, et al., 1976), and Leg 92 (this volume). Data from Legs 8 and 34 were converted to the Leg 92 biostratigraphy. For the eight sites analyzed, we determined the point at which each location was characterized by: (1) ongoing $\mathrm{CaCO}_{3}$ deposition at rates typical of the oligotrophic ocean; (2) an order of magnitude reduction in the linear sedimentation rate, but with the sediments still being rich in $\mathrm{CaCO}_{3}$; and (3) reduction of the $\mathrm{CaCO}_{3}$ content of the sediments to zero. The last point is a functional definition of the sedimentary CCD (Berger et al., 1976). We presume that the large rate decrease records the influence of the lysocline. The times of these changes are plotted along the subsidence curves to reveal the geologic history of the South Pacific CCD and lysocline (Fig. 3).

\section{DISCUSSION}

\section{Nature and History of Crustal Subsidence}

The history of lithospheric formation and ensuing subsidence in the southeast Pacific is complex. The present East Pacific Rise in this region was created by wester-

Table 1. Subsidence and calcite accumulation data for South Pacific DSDP drill sites.

\begin{tabular}{|c|c|c|c|c|c|c|c|c|}
\hline Leg, site & $\begin{array}{l}\text { Latitude, } \\
\text { longitude }\end{array}$ & $\begin{array}{c}\text { Water } \\
\text { depth (m) }\end{array}$ & $\begin{array}{c}\text { Sediment } \\
\text { thickness (m) }\end{array}$ & $\begin{array}{l}\text { Unloaded } \\
\text { basement } \\
\text { depth }(\mathrm{m})^{\mathrm{a}}\end{array}$ & $\begin{array}{l}\text { Basement } \\
\text { age (Ma) }\end{array}$ & $\begin{array}{c}\text { Subsidence } \\
\text { parameter, } k\end{array}$ & $\begin{array}{c}\text { Age (Ma) when } \\
Z=C C D\end{array}$ & $\begin{array}{l}\text { Age }(\mathrm{Ma}) \text { of } \times 10 \\
\text { reduction } \\
\text { in } \mathrm{LSR}^{\mathrm{b}}\end{array}$ \\
\hline 8,75 & $12^{\circ} 31^{\prime} \mathrm{S}, 134^{\circ} 16^{\prime} \mathrm{W}$ & 4181 & 82 & 4222 & 34.0 & 0.252 & 20.0 & 20.0 \\
\hline 34,319 & $13^{\circ} 01^{\prime} \mathrm{S}, 101^{\circ} 32^{\prime} \mathrm{W}$ & 4296 & 110 & 4351 & 15.0 & 0.413 & 5.0 & 13.5 \\
\hline 34,320 & $9^{\circ} 00^{\prime} \mathrm{S}, 83^{\circ} 32^{\prime} \mathrm{W}$ & 4487 & 155 & 4565 & 23.0 & 0.378 & $<15.0^{\mathrm{c}}$ & \\
\hline 34,321 & $12^{\circ} 01^{\prime} \mathrm{S}, 81^{\circ} 54^{\prime} \mathrm{W}$ & 4827 & 124 & 4889 & 38.0 & 0.347 & 24.0 & 24.0 \\
\hline 92,597 & $18^{\circ} 49^{\prime} \mathrm{S}, 129^{\circ} 46^{\prime} \mathrm{W}$ & 4164 & 53 & 4190 & 28.6 & 0.269 & 14.2 & 17.0 \\
\hline 92,598 & $19^{\circ} 00^{\prime} \mathrm{S}, 124^{\circ} 41^{\prime} \mathrm{W}$ & 3699 & $60^{\mathrm{d}}$ & 3730 & 16.0 & 0.245 & e & 8.1 \\
\hline 92,599 & $19^{\circ} 27^{\prime} \mathrm{S}, 119^{\circ} 53^{\prime} \mathrm{W}$ & 3654 & 41 & 3675 & 8.0 & 0.327 & e & 3.7 \\
\hline 92,601 & $18^{\circ} 55^{\prime} \mathrm{S}, 116^{\circ} 52^{\prime} \mathrm{W}$ & 3433 & 20 & 3443 & 4.6 & 0.323 & e & f \\
\hline
\end{tabular}

a Sediments depress basement by half their thickness (Berger, 1973).

b LSR = linear sedimentation rate.

c Site 320 was spot cored; youngest carbonate recovered is about $15 \mathrm{Ma}$.

d Estimated from seismic reflection records and comparison to adjacent sites.

e Site shallower than CCD.

f Site shallower than lysocline.

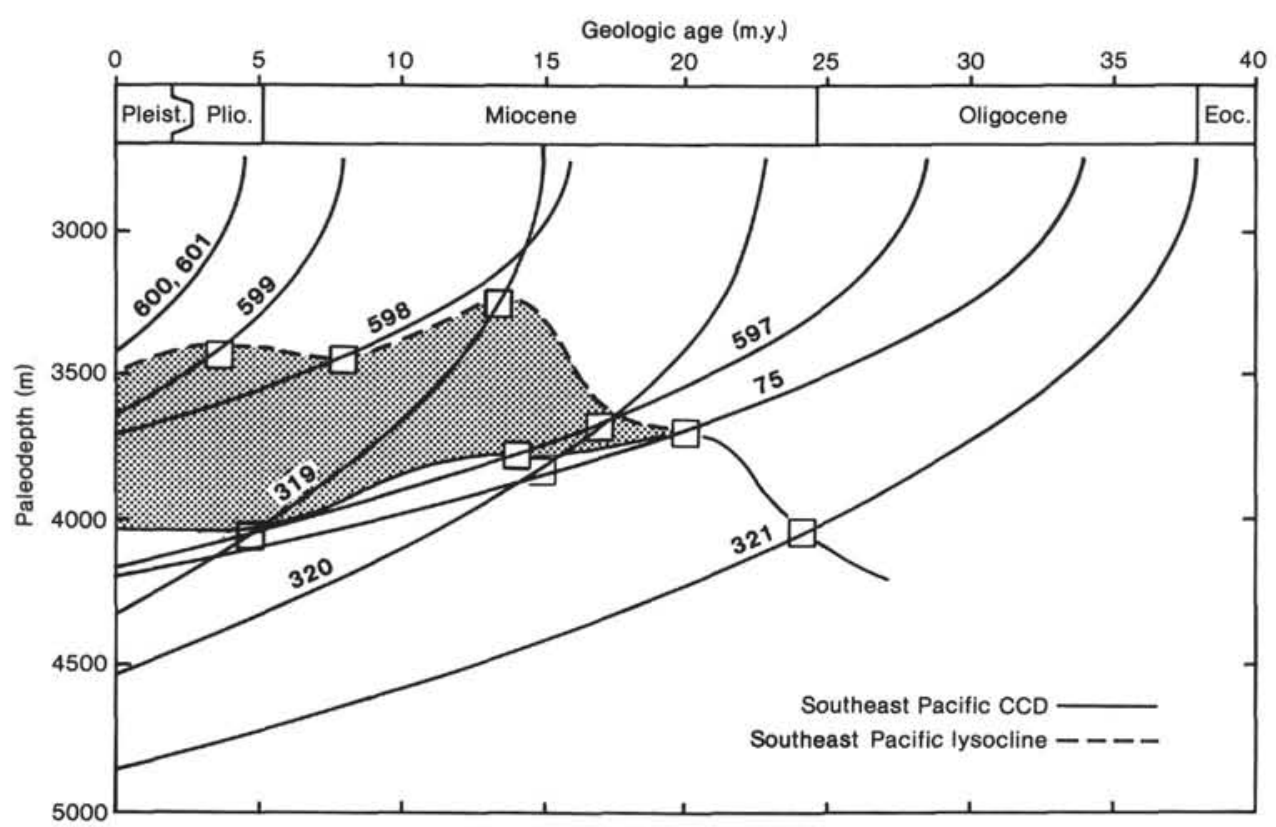

Figure 3. $\mathrm{CaCO}_{3}$ accumulation record plotted on age-depth curves for sites in the southeast Pacific. Squares are $1 \mathrm{~m} . \mathrm{y} . \times 100 \mathrm{~m}$ in dimension and provide an indication of accuracy. Shaded region emphasizes the depth zone of the lysocline. 
ly jumps of the fossil Galapagos Rise spreading system that occurred at about $20 \mathrm{Ma}$ south of the Garrett Fracture Zone at $13^{\circ} \mathrm{S}$, and at 5 to $8 \mathrm{Ma}$ to the north of the fracture zone (Handschumacher, 1976; Herron, 1972; Mammerickx, 1975; Mammerickx et al., 1980; Rea, 1981). The fracture zone at $13^{\circ} \mathrm{S}$ may also divide the symmetrically spreading, northern section of the East Pacific Rise from the asymmetrically spreading portion to the south (Rea, 1981). The asymmetrically spreading portion of the Rise, caused by a faster spreading rate to the east, corresponds geographically to a broad region of marked depth asymmetry, which is shallower to the west (Mammerickx, 1975; Mammerickx and Smith, 1978). Subsidence rates can be calculated for the modern Rise axis. The east flank has a subsidence parameter of 0.40 , both at $11^{\circ} \mathrm{S}$, where spreading is symmetrical, and at $20^{\circ} \mathrm{S}$, where it is asymmetrical (Rea, 1976, 1978). The slower spreading west flank at $20^{\circ} \mathrm{S}$ ( 70 versus $92 \mathrm{~mm} / \mathrm{yr}$.) has a low subsidence parameter value of about 0.25 (Rea, 1978).

Consideration of these several factors does not yet explain all of the subsidence patterns shown in Figure 2, because they imply similar subsidence histories for the same flank of each spreading system. Sites 320 and 321 are located on the east flank of the old Galapagos Rise system and should have similar subsidence parameters, as should Sites 75, 597, and 319 located on the west flank of the Galapagos Rise, and Sites 598, 599, and 601 on the west flank of the East Pacific Rise. The difference in subsidence histories of Sites 75 and 597 versus 319 , and (to a lesser extent) Site 598 versus 599 and 601 , may be instructive. Those discrepancies suggest that some event or process, occurring since the lithosphere was formed, has retarded normal subsidence on the west flank of the East Pacific Rise. Sites 597 and 75 are 800 to $1000 \mathrm{~m}$ shallower than the extrapolated depth of Site 319 , and Site 598 lies $250 \mathrm{~m}$ shallower than the extrapolated depths of Sites 599 and 601 . The cause of these differences in subsidence, presumably thermal in nature, may either (1) have affected all locations west of the Rise axis at some time between 16 and $8 \mathrm{Ma}$, or (2) be a continuing process that affects regions west of about $120^{\circ} \mathrm{W}$.

\section{History of the CCD and Lysocline}

The eight sites chosen for this study provide a considerable amount of information about the history of the lysocline and the CCD (Fig. 3 and Table 1). Site 601 has always been above the lysocline. Sites 598 and 599 are now below the lysocline and above the CCD. Sites 319 and 597 have passed through both the lysocline and the CCD. The two oldest sites, 75 and 321 , passed through the CCD abruptly with no prior evidence of a reduced calcite accumulation rate before reaching the CCD. Site 320 was spot cored; the age of youngest calcareous sediment recovered there is $15 \mathrm{Ma}$. Nevertheless, the reasonable agreement of the CCD from Site 597 with the maximum age of the transition through the CCD at Site 320 provides a welcome indication of the reliability of our data.
The CCD in the South Pacific was at about $4200 \mathrm{~m}$ depth in late Oligocene time, was shoaled at about 500 to $3700 \mathrm{~m}$ in middle early Miocene, and has deepened since then to the present depth of about $4100 \mathrm{~m}$ (Fig. 3). This history is similar to that determined by van Andel et al. (1975) for the nonequatorial Pacific.

The absence of a zone of increased dissolution or reduced $\mathrm{CaCO}_{3}$ sedimentation above the $\mathrm{CCD}$ at Sites 75 and 321 suggests that the lysocline was not well developed before 17 to $20 \mathrm{Ma}$. From that time to $13.5 \mathrm{Ma}$, it shoaled by $600 \mathrm{~m}$. This $600 \mathrm{~m}$ dissolution zone (shaded on Fig. 3) remained with little variation until middle Pliocene, after which the lysocline deepened somewhat. Linear sedimentation rates for $\mathrm{CaCO}_{3}$-rich sediment above the lysocline at Sites 601, 599, 598, and 597 and above the CCD at Sites 75 and 321 are all about 3 to $10 \mathrm{~m} /$ m.y. Site 319 displays higher rates of $11 \mathrm{~m} / \mathrm{m}$.y. just above the CCD and rates of $35 \mathrm{~m} / \mathrm{m}$.y. for older, shallower sediments.

Development of a distinct lysocline above the CCD beginning in early Miocene may signify an important change in the hydrography of the deep Pacific Ocean. If the top of the lysocline coincides with the benthic thermocline (van Andel et al., 1975), then our data suggest an increase in the volume of more corrosive bottom water, which (within the accuracy of our data) occurs during the same time span as the inferred ice build-up in Antarctica at 12.4 to $16.0 \mathrm{Ma}$ (oxygen isotope stratigraphy from Woodruff et al., 1981; foraminifer zonation and time scale from Kennett and Srinivasan, 1983).

Broecker and Peng (1982) have suggested that the thickness of the lysocline zone of rapid $\mathrm{CaCO}_{3}$ dissolution varies directly with the downward flux of calcite. If this is true, then the early Miocene separation of the lysocline and CCD may be related to increased surface-water productivity beginning at that time. We note, however, that sediment accumulation rates above the lysocline at the younger sites are not different from those above the CCD at the older Sites 75 and 321 .

\section{ACKNOWLEDGMENTS}

We thank the sedimentologists and paleontologists on board the Glomar Challenger during Leg 92 for their efforts, which resulted in much of the data presented here. Nick Pisias and Wolf Berger reviewed this manuscript and made numerous useful comments and suggestions.

\section{REFERENCES}

Berger, W. H., 1967. Foraminiferal ooze: solution at depth. Science (Washington, D.C.), 156:383-385.

1968. Planktonic foraminifera: selective solution and paleoclimatic interpretation. Deep Sea Res., 15:31-43.

1970. Planktonic foraminifera: selective solution and the lysocline. Mar. Geol., 8:111-138.

1973. Cenozoic sedimentation in the eastern tropical Pacific. Geol. Soc. Am. Bull., 84:1941-1954.

Berger, W. H., Adelseck, C. G., Jr., and Mayer, L. A., 1976. Distribution of carbonate in surface sediments of the Pacific Ocean. $J$. Geophys. Res., 81:2617-2627.

Bramlette, M. N., 1961. Pelagic sediments. In Sears, M. (Ed.), Oceanography. Am. Assoc. Adv. Sci. Publ., 67:345-366.

Broecker, W. S., and Broecker, S., 1974. Carbonate dissolution on the western flank of the East Pacific Rise. In Hay, W. W. (Ed.), Studies in Paleooceanography. Soc. Econ. Paleontol. Mineral. Spec. Publ., 20:44-57. 
Broecker, W. S., and Peng, T.-H., 1982. Tracers in the Sea: New York (Lamont-Doherty Geol. Obs.).

Davis, E. E., and Lister, C. R. B., 1974. Fundamentals of ridge crest topography. Earth Planet. Sci. Lett., 21:405-413.

Handschumacher, D. W., 1976. Post-Eocene plate tectonics of the Eastern Pacific. In Sutton, G. H., Manghnani, M. H., and Moberly, R. (Eds.), The Geophysics of the Pacific Ocean Basin and its Margin. Am. Geophys. Union Geophys. Monogr., 19:177-202.

Heath, G. R., 1969. Carbonate sedimentation in the abyssal equatorial Pacific during the past 50 million years. Geol. Soc. Am. Bull., 80:689-694.

Heath, G. R., and Culberson, C., 1970. Calcite: degree of saturation, rate of dissolution, and the compensation depth in the deep oceans. Geol. Soc. Am. Bull., 81:3157-3160.

Herron, E. M., 1972. Sea-floor spreading and the Cenozoic history of the east-central Pacific. Geol. Soc. Am. Bull., 83:1671-1692.

Kennett, J. P., and Srinivasan, M. S., 1983. Neogene Planktonic Foraminifera: a Phylogenetic Atlas: Stroudsburg, Pa. (Hutchinson Ross).

Mammerickx, J., Anderson, R. N., Menard, H. W., and Smith, S. M., 1975. Morphology and tectonic evolution of the east-central Pacific. Geol. Soc. Am. Bull., 86:111-118.

Mammerickx, J., Herron, E., and Dorman, L., 1980. Evidence for two fossil spreading ridges in the southeast Pacific. Geol. Soc. Am. Bull., 91:263-271.

Mammerickx, J., and Smith, S. M., 1978. Bathymetry of the Southeast Pacific. Geol. Soc. Am. Map and Chart Series, MC-26.

Murray, J., and Renard, A. F., 1891. Report on deep-sea deposits based on the specimens collected during the voyage of H.M.S. Challenger in the years 1872-1876. Challenger Expedition Reports: H.M.S.O. (London).

Parker, R. L., and Oldenburg, D. W., 1973. Thermal model of ocean ridges. Nature Phys. Sci., 242:137-139.

Peterson, M. N. A., 1966. Calcite rates of dissolution in a vertical profile in the central Pacific. Science (Washington, D.C.), 154:15421544.
Rea, D. K., 1976. Analysis of a fast-spreading rise crest: the East Pacific Rise, $9^{\circ}$ to $12^{\circ}$ South. Mar. Geophys. Res., 2:291-313.

1978. Asymmetric seafloor spreading and a nontransform axis offset: the East Pacific Rise $20^{\circ} \mathrm{S}$ survey area. Geol. Soc. Am. Bull., 89:836-844.

1981. Tectonics of the Nazca-Pacific divergent plate boundary. In Kulm, L. D., Dymond, J., Dasch, E. J., and Hussong, D. M., (Eds.), Nazca Plate: Crustal Formation and Andean Convergence. Mem. Geol. Soc. Am., 154:27-62.

Sclater, J. G., Anderson, R. N., and Bell, M. L., 1971. The elevation of ridges and the evolution of the central Pacific. J. Geophys. Res., 76:7888-7915.

Tracey, J. I., Jr., Sutton, G. H., et al., 1971. Init. Repts. DSDP, 8: Washington (U.S. Govt. Printing Office).

van Andel, T. H., and Bukry, D., 1973. Basement ages and basement depths in the eastern equatorial Pacific from Deep Sea Drilling Project Legs 5, 8, 9, and 16. Geol. Soc. Am. Bull., 84:2361-2370.

van Andel, T. H., Heath, G. R., and Moore, T. C., Jr., 1975. Cenozoic History and Paleoceanography of the Central Equatorial Pacific Ocean. Mem. Geol. Soc. Am., 143.

van Andel, T. H., and Moore, T. C., Jr., 1974. Cenozoic calcium carbonate distribution and calcite compensation depth in the central equatorial Pacific Ocean. Geology, 2:87-92.

Woodruff, F., Savin, S. M., and Douglas, R. G., 1981. Miocene stable isotope record: a detailed deep Pacific Ocean study and its paleoclimatic implications. Science (Washington, D. C.), 212:665-668.

Yeats, R. S., Hart, S. R., et al., 1976. Init. Repts. DSDP, 34: Washington (U.S. Govt. Printing Office).

Date of Initial Receipt: 2 July 1984

Date of Acceptance: 26 December 1984 